\title{
The Doug Martin Site (41AN88), a Late Caddo Period Frankston Phase Settlement in the Trinity River Basin in East Texas
}

Timothy K. Perttula

Heritage Research Center, Stephen F. Austin State University

Follow this and additional works at: https://scholarworks.sfasu.edu/ita

Part of the American Material Culture Commons, Archaeological Anthropology Commons, Environmental Studies Commons, Other American Studies Commons, Other Arts and Humanities Commons, Other History of Art, Architecture, and Archaeology Commons, and the United States History Commons

Tell us how this article helped you.

This Article is brought to you for free and open access by the Center for Regional Heritage Research at SFA ScholarWorks. It has been accepted for inclusion in Index of Texas Archaeology: Open Access Gray Literature from the Lone Star State by an authorized editor of SFA ScholarWorks. For more information, please contact cdsscholarworks@sfasu.edu. 


\section{The Doug Martin Site (41AN88), a Late Caddo Period Frankston Phase Settlement in the Trinity River Basin in East Texas}

\section{Creative Commons License}

\section{(c) (1) \&}

This work is licensed under a Creative Commons Attribution-NonCommercial 4.0 International License 


\title{
The Doug Martin Site (41AN88), a Late Caddo Period Frankston Phase Settlement in the Trinity River Basin in East Texas
}

\author{
Timothy K. Perttula
}

\section{INTRODUCTION}

The Doug Martin site (41AN88) is a Late Caddo period Frankston phase settlement on a southernflowing tributary to the Trinity River in the Post Oak Savannah of East Texas (Figure 1). Several avocational archaeologists from the Palestine, Texas, area, principally including Clyde Amick, worked at the site in the early 1980s, and donated a collection of artifacts from the site, along with some information about the work done there, to the Texas Archeological Research Laboratory at The University of Texas at Austin (TARL) in November 1985.

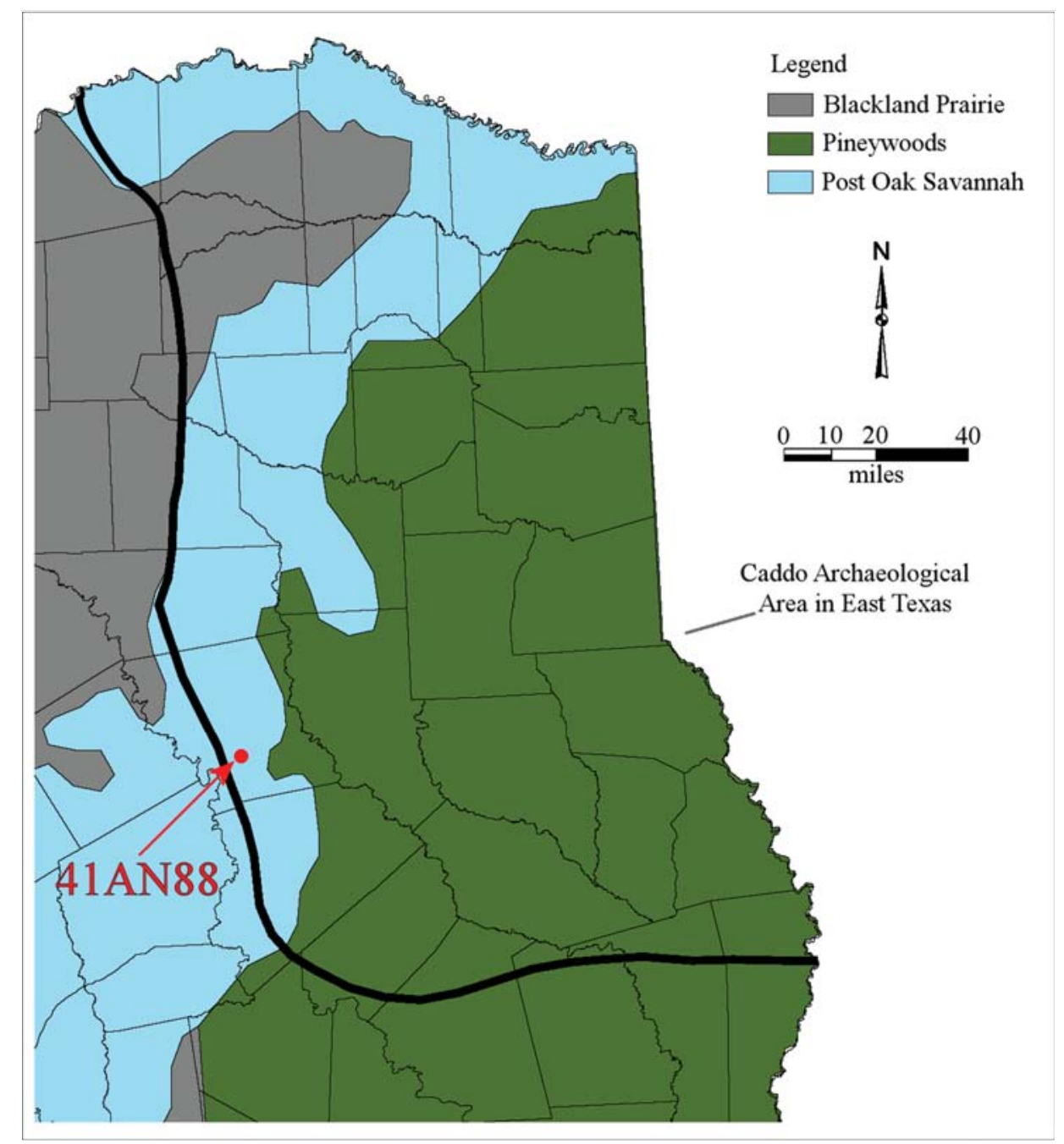

Figure 1. The location of the Doug Martin site in East Texas. 


\section{SITE SETTING AND INVESTIGATIONS}

The Doug Martin site is situated on a small sandy knoll, ca. $30 \times 18 \mathrm{~m}$ in length and width, and ca. 1.5 $\mathrm{m}$ in height, along Manson Creek, a southern-flowing tributary to the Trinity River. The knoll is ca. $3.6 \mathrm{~m}$ above the creek bed.

The sandy knoll has a well-preserved midden deposit with charcoal, burned clay pieces, animal bones, and teeth, ceramic sherds, and chipped and ground stone tools. The work done at the site consisted of surface collections of the plowed knoll, probing with an iron rod, and the excavation and screening of test pits of unknown size. During the work, more than 2000 animal bones were recovered from the site, including deer, turtle, and small mammals.

\section{ARTIFACT ASSEMBLAGE}

The artifact assemblage from the Doug Martin site includes both ceramic and lithic artifacts. The ceramic artifacts are comprised of both Woodland period and ancestral Caddo sherds, a ceramic elbow pipe, and a few pieces of burned clay and daub. The lithic artifacts from the site include both dart points and arrow points as well as a ground stone celt.

\section{Caddo Ceramic Sherds}

The ancestral Caddo ceramic assemblage consists of 1146 rim, body, and base sherds from vessels tempered with either grog (81.7 percent) or bone (18.3 percent) (Table 1); all three wares are tempered with roughly equivalent proportions of either grog or bone. The plain to decorated sherd ratio is 1.65 . About 92 percent of the decorated sherds are from utility ware vessels (with wet paste decorations), and 8 percent are from fine ware vessels (with engraved and slipped decorations).

Table 1. Caddo ceramic sherd assemblage from the Doug Martin site.

\begin{tabular}{lrrrr}
\hline Ware & Grog & Bone & N & Percent \\
\hline Plain & 589 & 124 & 713 & 63.2 \\
Utility & 321 & 79 & 400 & 34.9 \\
Fine & 26 & 7 & 33 & 2.9 \\
\hline Totals & 936 & 210 & 1146 & 100.0 \\
\hline
\end{tabular}

Of the 56 rim sherds in the ceramic assemblage, 55.4 percent are from utility ware vessels $(n=31)$, another 30.4 percent are from plain ware bowls and jars, and only 14.3 of the rims are from fine ware vessels. These proportions clearly indicate that utility ware and plain ware vessels dominate the Doug Moore ceramic assemblage overall.

Rim and body sherds with brushing marks comprise 57 percent of the utility wares (Table 2), followed by sherds from vessels with incised (20 percent) and punctated (17 percent) decorative elements; the overall proportion of brushed sherds in both the decorated assemblage as a whole or amongst just the utility wares is consistent with a Frankston phase occupation (Perttula 2011:Table 6-38). However, comparing the proportion of rim sherds only, more than 41 of the rim sherds are from incised vessels, 26 percent are from vessels with punctated rims, 16 percent are from brushed vessels, and 13 percent are from vessels with incised-punctated rim decorative elements; thus, other wet paste decorative elements were important in the utility ware vessels from the Doug Moore site. 
Table 2. Utility ware sherds from the Doug Moore site.

\begin{tabular}{llll}
\hline $\begin{array}{l}\text { Decorative method/ } \\
\text { Decorative element }\end{array}$ & Rim & Body & N \\
\hline
\end{tabular}

\section{Appliqued}

large appliqued node

straight appliqued ridge

\section{Brushed}

diagonal brushed

horizontal brushed

opposed brushed

overlapping brushed

parallel brushed

vertical brushed

\section{Brushed-Incised}

parallel brushed-incised

parallel brushed and overlying

parallel incised lines

vertical brushed-incised

\section{Brushed-Punctated}

diagonal brushing marks and tool

punctated row at rim-body juncture

\section{Incised}

cross-hatched lines

curvilinear arcing lines

diagonal lines

diagonal lines, L-R

diagonal lines, R-L

diagonal opposed lines

horizontal line under lip

horizontal lines

horizontal and diagonal lines, L-R

horizontal and diagonal opposed lines

opposed lines

parallel lines

straight line

\section{Incised-Punctated}

cross-hatched lines and triangular zone filled with tool punctates

diagonal lines and triangular zone with linear tool punctates

diagonal opposed lines divided by row of tool punctates
1

$-$

1

1

$\begin{array}{rrr}1 & - & 1 \\ 3 & - & 3 \\ - & 2 & 2 \\ - & 4 & 4 \\ - & 218 & 218 \\ 1 & - & 1\end{array}$

$\begin{array}{lll}- & 2 & 2 \\ - & 1 & 1 \\ - & 1 & 1\end{array}$

1

7

2

1

2

5

4

1

1

5

1

3

19

28

1

1

1 
Table 2. Utility ware sherds from the Doug Moore site, cont.

\begin{tabular}{|c|c|c|c|}
\hline $\begin{array}{l}\text { Decorative method/ } \\
\text { Decorative element }\end{array}$ & $\operatorname{Rim}$ & Body & $\mathrm{N}$ \\
\hline $\begin{array}{l}\text { diagonal and curvilinear lines } \\
\text { and circular zone filled with } \\
\text { tool punctates }\end{array}$ & 1 & - & 1 \\
\hline $\begin{array}{l}\text { horizontal lines with crescent- } \\
\text { shaped punctated rows }\end{array}$ & 1 & - & 1 \\
\hline $\begin{array}{l}\text { horizontal and diagonal lines and } \\
\text { triangular zone with linear tool } \\
\text { punctates }\end{array}$ & - & 1 & 1 \\
\hline $\begin{array}{l}\text { horizontal and vertical lines and } \\
\text { vertical tool punctated row }\end{array}$ & - & 1 & 1 \\
\hline $\begin{array}{l}\text { straight line and adjacent tool } \\
\text { punctated zone }\end{array}$ & - & 7 & 7 \\
\hline triangle element with tool punctates & 1 & - & 1 \\
\hline \multicolumn{3}{|l|}{ Pinched } & 2 \\
\hline \multicolumn{4}{|l|}{ Punctated } \\
\hline circular punctated rows & 1 & - & 1 \\
\hline small circular punctated rows & 1 & - & 1 \\
\hline fingernail punctated rows & - & 13 & 13 \\
\hline linear tool punctated rows & - & 1 & 1 \\
\hline tool punctated rows & 6 & 45 & 51 \\
\hline \multicolumn{4}{|l|}{ Trailed } \\
\hline Totals & 31 & 369 & 400 \\
\hline
\end{tabular}

$\mathrm{L}-\mathrm{R}=$ left-right; incised lines begin at the left at the rim and end at the right at the bottom of the rim; $\mathrm{R}-\mathrm{L}=$ incised lines begin at the right at the rim and end at the left at the bottom of the rim

The one appliqued rim has a large appliqued node, and likely is from an effigy vessel. The body sherd with the straight appliqued ridge, but plain panels, may be from a La Rue Neck Banded jar (see Suhm and Jelks 1962:Plate 33b). The brushed, brushed-incised, and brushed-punctated rim and body sherds are from Bullard Brushed jars. They have diagonal, horizontal, and vertical brushed rims (see Table 2).

The sherds with incised and incised-punctated decorative elements (see Table 2) are almost exclusively from Maydelle Incised jars. They have diagonal and diagonal opposed incised lines (Figure 2d-g) on jar rims, as well as diagonal incised lines forming triangular zones filled with tool punctations (Figure $2 b$ ). Two body sherds have vertical rows of tool punctations with opposed diagonal and horizontal incised lines in panels on vessel bodies (Figure 2a, c). One rim sherd is from a pre-A.D. 1300 Weches Fingernail Impressed, var. Weches jar with crescent-shaped rows of fingernail punctations between sets of horizontal incised lines (see Stokes and Woodring 1981). Horizontal incised lines are on the rims of both bowls and jars (see Table 2). 


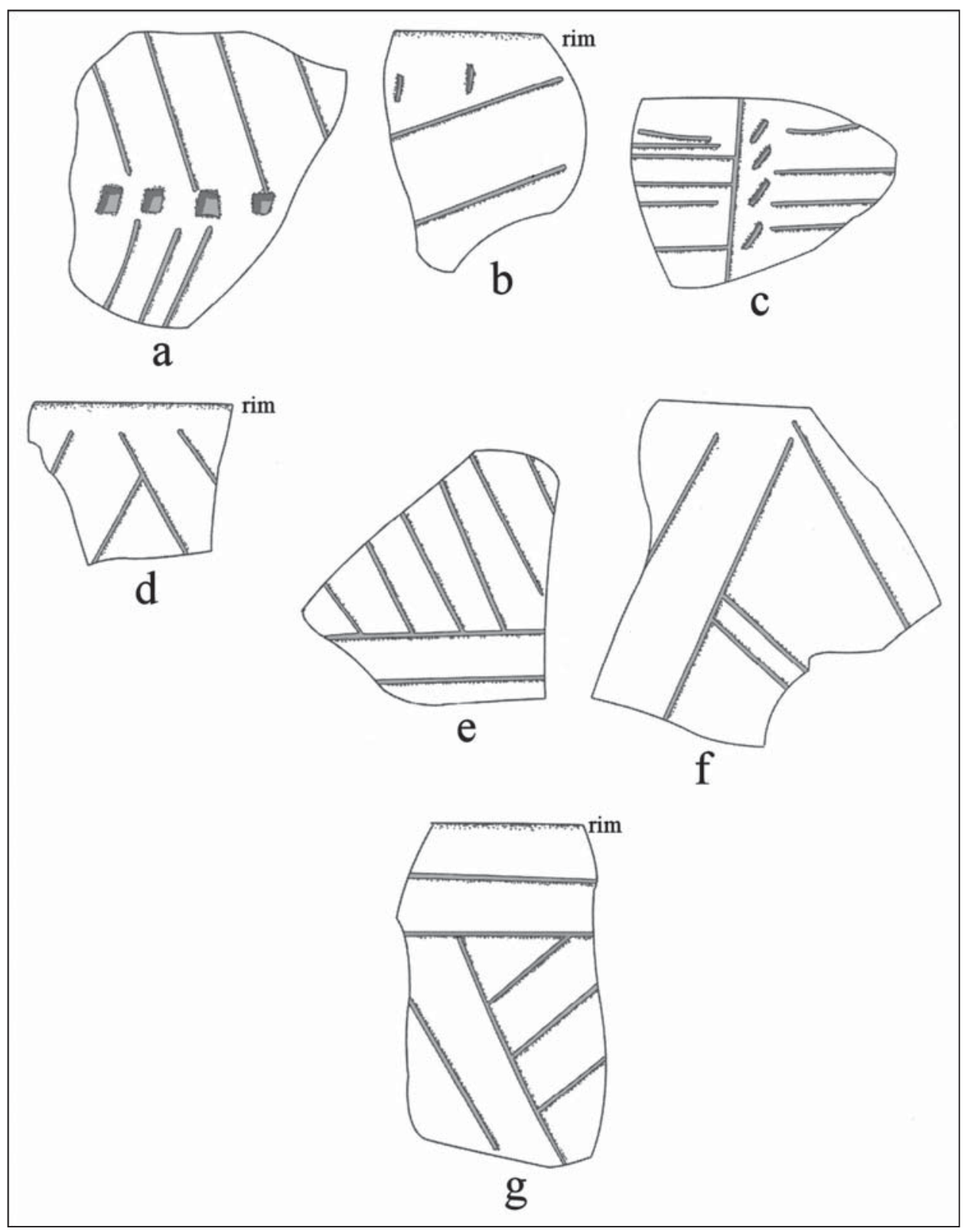

Figure 2. Selected decorative elements on utility ware rim and body sherds from the Doug Martin site (41AN88): a-c, incised-punctated; d-g, incised.

The two body sherds with pinched ridges are from the bodies of Killough Pinched jars (see Table 2). The one trailed body sherd in the utility wares is likely from a Foster Trailed-Incised jar (see Suhm and Jelks 1962:43). Other vessels in the assemblage are jars with rows of punctations on the rim, either circular punctations or tool punctations (see Table 2). Vessel bodies were likely covered with rows or randomly placed fingernail and tool punctations.

The fine ware sherds from the Doug Moore site are from vessels with engraved, engraved-brushed, and red-slipped decorative elements (Table 3). About 88 percent of the fine ware sherds are from vessels with engraved designs, 3 percent engraved-brushed, and 9 percent with red-slipped interior and exterior surfaces; the red-slipped sherds are all from bone-tempered vessels, suggesting-given the overall low proportion of bone-tempered vessels in the assemblage - that these sherds may be from vessels made from another part of East Texas, perhaps the upper Sabine River basin where red-slipped vessels are more common in the fine wares. 
Table 3. Fine ware sherds from the Doug Moore site.

\begin{tabular}{|c|c|c|c|}
\hline $\begin{array}{l}\text { Decorative method/ } \\
\text { Decorative element }\end{array}$ & Rim & Body & $\mathrm{N}$ \\
\hline \multicolumn{4}{|l|}{ Engraved } \\
\hline curvilinear lines & - & 2 & 2 \\
\hline curvilinear and arcing lines, closely-spaced & - & 2 & 2 \\
\hline hatched zone, curvilinear & - & 1 & 1 \\
\hline hatched zone, narrow & - & 1 & 1 \\
\hline hatched triangle and straight line & - & 4 & 4 \\
\hline horizontal lines & 2 & - & 2 \\
\hline $\begin{array}{l}\text { horizontal line and circular el., } \\
\text { with excised punctations within the circles }\end{array}$ & 1 & - & 1 \\
\hline horizontal line and cross-hatched bracket & 1 & - & 1 \\
\hline horizontal line and open pendant triangles & 2 & - & 2 \\
\hline $\begin{array}{l}\text { horizontal, diagonal, and } \\
\text { curvilinear arcing lines }\end{array}$ & - & 2 & 2 \\
\hline $\begin{array}{l}\text { horizontal and diagonal lines and } \\
\text { excised triangle el. }\end{array}$ & - & 1 & 1 \\
\hline $\begin{array}{l}\text { horizontal and diagonal lines and } \\
\text { attached hatched triangle el. }\end{array}$ & 1 & - & 1 \\
\hline $\begin{array}{l}\text { horizontal and vertical lines and } \\
\text { nested oval in triangle el. }\end{array}$ & - & 1 & 1 \\
\hline parallel lines & - & 3 & 3 \\
\hline straight line & - & 3 & 3 \\
\hline vertical cross-hatched panel & 1 & - & 1 \\
\hline $\begin{array}{l}\text { vertical and diagonal lines, and } \\
\text { open pendant triangles }\end{array}$ & - & 1 & 1 \\
\hline $\begin{array}{l}\text { Engraved-Brushed } \\
\text { curvilinear opposed lines and } \\
\text { horizontal line; horizontal brushed body }\end{array}$ & - & 1 & 1 \\
\hline \multicolumn{4}{|l|}{ Red-Slipped } \\
\hline int./exterior red-slipped & - & 3 & 3 \\
\hline Totals & 8 & 25 & 33 \\
\hline
\end{tabular}

There are several varieties of Poynor Engraved vessels (see Perttula 2011:Figures 6-64 and 6-65) in the fine ware sherds from the Doug Moore site. This includes var. Lang $(\mathrm{n}=1)$, with circular elements filled with excised punctations (Figure 3a), var. Cook with curvilinear arcing lines (Figure 3h-i), among them one sherd with a horizontal brushed body, var. Hood with a cross-hatched bracket on the rim panel (Figure 3e), Var. D with vertical cross-hatched panels (Figure 3d), probably Var. $F$ with nested ovals (Figure 3b, k), Var. A with nested triangles (Figure 3g), Var. P' (Figure 3f) with a hatched hooked arm element, and Var. $T$ diagonals with small pendant triangles (Figure $3 \mathrm{j}$ ). Two other rim sherds have small continuous row of pendant triangles on a horizontal engraved line below the lip (Figure 3c); this decorative element may be related to Var. $C$ of Poynor Engraved in the upper Neches River basin (Perttula 2011:Figure 6-65). 


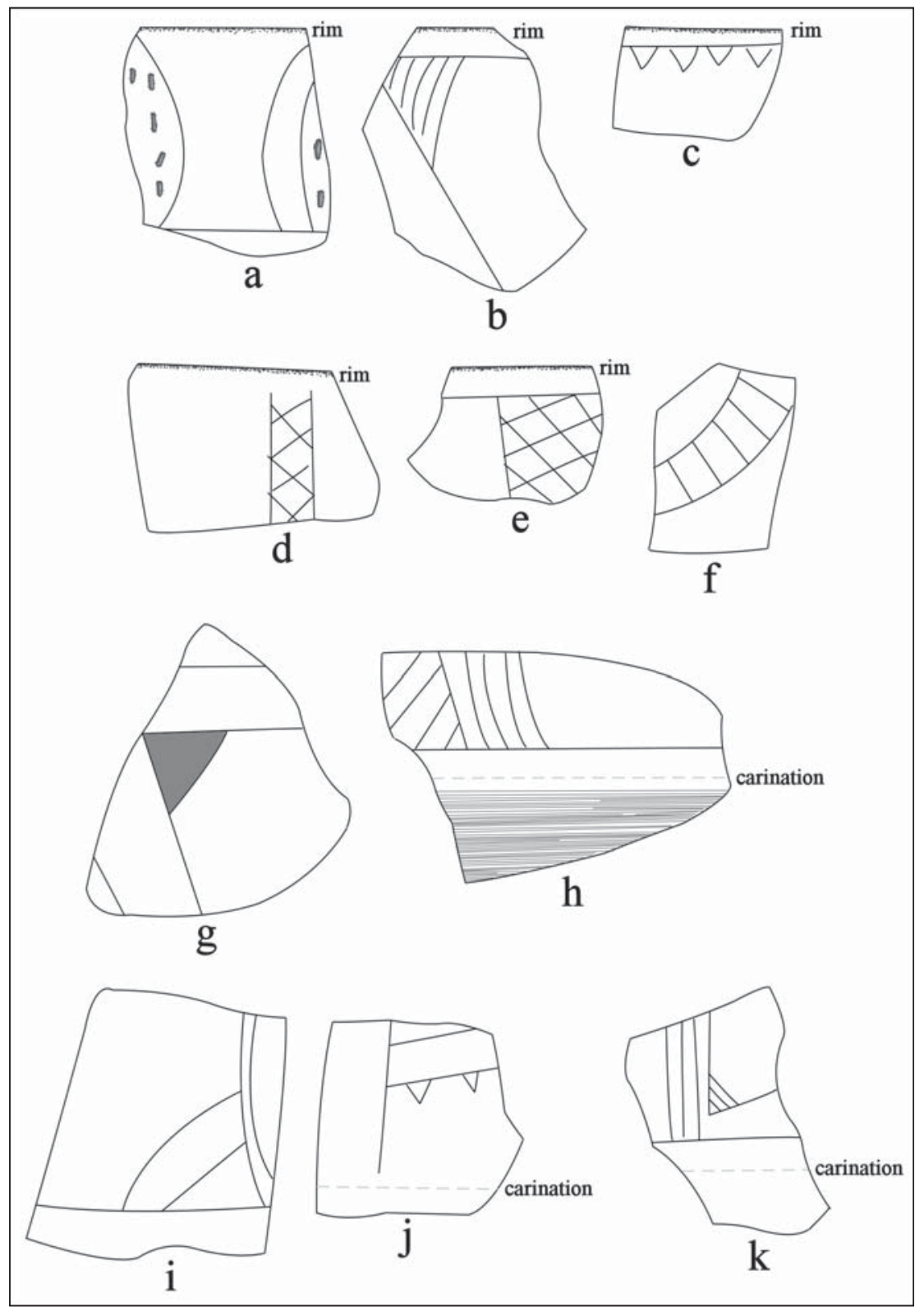

Figure 3. Selected decorative elements on fine ware rim and body sherds from the Doug Martin site (41AN88): a, engraved-punctated; b-g, i-k, engraved; $\mathrm{h}$, engraved-brushed.

The absence of Poynor Engraved, var. Freeman in the Poynor Engraved fine ware sherds from the Doug Moore site strongly suggests that the ancestral Caddo occupation took place before ca. A.D. 1560, or subphase 3 of the Frankston phase in the region. In the upper Neches River basin, the aforementioned varieties of Poynor Engraved from the Doug Moore site occur in the frequency seriation of engraved fine ware vessels in burial features in that basin that have been estimated to date from ca. A.D. 1400-1560 (Perttula 2011:Table 6-37). In fact, the highest frequencies of these Poynor Engraved varieties are estimated to date between ca. A.D. 1480-1560 on upper Neches River basin Caddo sites. 


\section{Caddo Ceramic Pipe}

The donated TARL collection from the Doug Moore site has a fragmentary upper Neches River basin style Var. B elbow pipe (Perttula 2011:215 and Figure 6-23) (Figure 4). The pipe has a flaring rim bowl (33.0 $\mathrm{mm}$ in diameter) and a distal stem knob. The stem itself has three horizontal incised lines on the stem and under the bowl. Var. B elbow pipes are found on ca. A.D. 1400-16650 Frankston phase site, including in ceremonial contexts at the A. C. Saunders site (41AN19) (Perttula 2011:215).

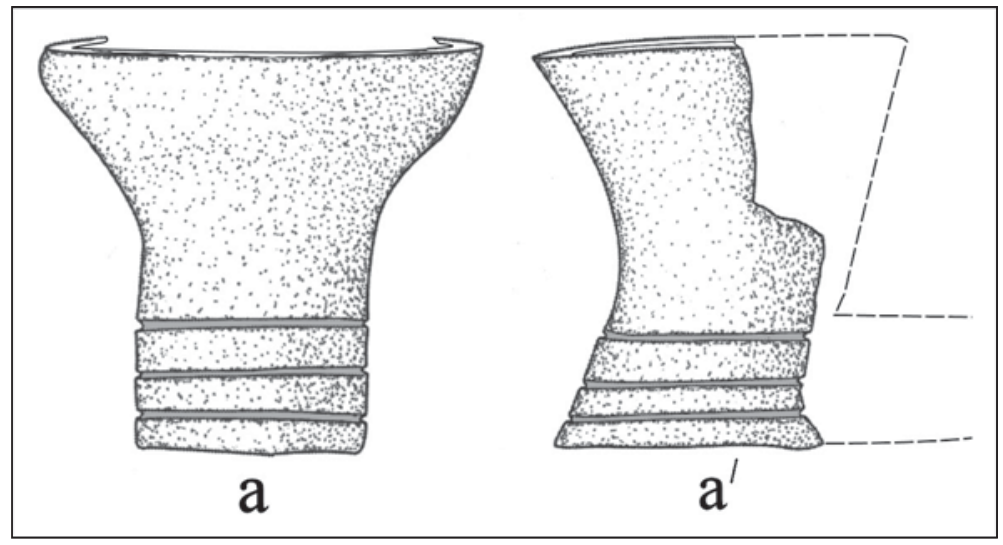

Figure 4. Elbow pipe fragment from the Doug Martin site (41 AN88):

a, back view; a', side view.

\section{Burned Clay and Daub}

The presence of both burned clay and daub pieces $(n=8)$ in the collection suggests that remnants of at least one burned thatch- and grass-covered Caddo house structure may be preserved at the site.

\section{Woodland Period Sandy Paste Sherds}

The occurrence of Goose Creek Plain, var. unspecified sandy paste sherds at the Doug Moore site, along with the recovery of both Gary and Kent dart points (see below), indicates that the site was occupied during some part of the Woodland period. The Goose Creek Plain ceramic assemblage includes two rims, 37 body sherds, and one base sherd. This ceramic ware is associated with Woodland period cultures in the southern part of East Texas, and the presence of sherds from this ware in the collection is evidence that the site was first occupied sometime during the Woodland period, between ca. 500 B.C. and A.D. 800 (see Ellis 2013; Perttula 2013).

\section{Projectile Points}

Although the projectile points from the site were not donated to TARL, they were reviewed by TARL personnel when Clyde Amick brought his collection to Austin for an examination. The collection included Gary, Kent, and Yarbrough dart points - principally Gary points - indicative of both Late Archaic and Woodland period use of the site by aboriginal groups. The few arrow points $(n=20)$ included arrow point preforms $(n=5)$, unidentifiable fragments $(n=4)$, a Perdiz point, two possible Cuney points, possible Friley and Hayes points, four unidentified points with expanding stems, and two arrow points with straight stems. 


\section{Ground Stone Tool}

A single ground stone celt was collected from the Doug Martin site. It likely is associated with the Late Caddo period Frankston phase occupation there.

\section{SUMMARY AND CONCLUSIONS}

The Doug Moore site (41AN88) is a multi-component archaeological site on a sandy knoll along Manson Creek, a tributary of the Trinity River in East Texas. The recovered lithic and ceramic artifacts from the site, collected by local avocational archaeologists in the early 1980s, suggest that the site was used by aboriginal groups during both the Late Archaic and Woodland periods, but the principal occupation was by an ancestral Caddo group who settled on the sandy knoll, and left a well-preserved midden deposit there as evidence of their use of the landform.

The artifacts broken and discarded by Caddo peoples at the site include several arrow points and a ground stone celt, pieces of burned clay and daub, numerous animal bones, a post-A.D. 1400 flaring rim elbow pipe fragment, and an abundance of vessel sherds from plain ware, utility ware, and fine ware vessels primarily tempered with grog. Utility ware vessels are primarily from Bullard Brushed and Maydelle Incised jars, along with vessels decorated with rows of punctations on their rims. Fine ware vessels are marked by sherds almost exclusively from a number of different varieties of Poynor Engraved, along with a few red-slipped sherds from one or more bone-tempered vessels. The numerous varieties of Poynor Engraved at the Doug Moore site are also well represented as common and regional varieties in Frankston phase sites in the upper Neches River basin, particularly sub-phase 2 Frankston phase sites that date from ca. A.D. 1480-1560.

\section{ACKNOWLEDGMENTS}

I thank Jonathan Jarvis at the Texas Archeological Research Laboratory at The University of Texas for facilitating access to the collections and records from the Doug Martin site. Lance Trask prepared the figures in this article.

\section{REFERENCES CITED}

Ellis, L. W.

2013 Woodland Ceramics in East Texas and a Case Study of Mill Creek Culture Ceramics. Bulletin of the Texas Archeological Society 84:137-180.

Perttula, T. K.

2011 The Ceramic Artifacts from the Lang Pasture Site (41AN38) and the Place of the Site within an Upper Neches River Basin Caddo Ceramic Tradition. In Archeological Investigations at the Lang Pasture Site (41AN38) in the Upper Neches River Basin of East Texas, assembled and edited by T. K. Perttula, D. B . Kelley, and R. A. Ricklis, pp. 145-320. Archeological Studies Program Report No. 129, Texas Department of Transportation, Environmental Affairs Division, Austin.

2013 Caddo Ceramics in East Texas. Bulletin of the Texas Archeological Society 84:181-212.

Stokes, J. and J. Woodring

1981 Native-Made Artifacts of Clay. In Archeological Investigations at the George C. Davis Site, Cherokee County, Texas: Summers of 1979 and 1980, edited by D. A. Story, pp. 135-238. Occasional Paper No. 1. Texas Archeological Research Laboratory, The University of Texas at Austin.

Suhm, D. A. and E. B. Jelks (editors)

1962 Handbook of Texas Archeology: Type Descriptions. Special Publication No. 1, Texas Archeological Society, and Bulletin No. 4, Texas Memorial Museum, Austin. Reprinted in 2009, Gustav's Library, Davenport, Iowa. 